\title{
Evaluation of University Review Program for Teachers' Licensure Examination: A Transformative Mixed Methods Study Using Bourdieu-Scheerens Framework
}

\author{
Fernigil L. Colicol ${ }^{*}$ \\ College of Education, Mindanao State University-Tawi-Tawi, Philippines \\ College of Education, University of the Philippines Diliman, Philippines \\ Charmine Z. Puig and Shielamar J. Judan \\ College of Education, Mindanao State University-Tawi-Tawi, Philippines
}

\begin{abstract}
Guided by the Bourdieu-Scheerens framework, this study uses transformative mixed methods exploratory sequential design to evaluate the "LET Intensive Review," a university program for the Licensure Examination for Teachers (LET). The review program is regarded as an input, a means for achieving an output. While analysis includes the context, inputs, process, and outputs in education function, close attention is given to processes to elucidate contributing factors in the LET outcomes. Ethnography as the primary research design was used to explore pre-service teachers' (PSTs) experiences in the review, deploying the Bourdieusian framework in the analysis. In support of the qualitative findings, a descriptive research design was employed. The Mann-Whitney $U$ Test and the Independent Samples $t$-test were performed to analyze the university passing percentage ratings in the LET elementary and secondary levels for first-timers before and during the conduct of the review. Integrative analysis of the qualitative and quantitative results followed to draw the mixed methods research findings. This evaluation reveals that the LET Intensive Review is effective, and the faculty agency and the administrator agency play a big part in the process. Most of the LET elementary level first-timers who took the review obtained significantly higher LET ratings than those from the previous batches who had not gone through the review. Financial constraints, weak basic education foundation, majorship, and low motivation affected the PSTs' performance and education quality. The educational policy implications related to the urban-rural divide are also presented in this study.
\end{abstract}

Keywords: Bourdieu; Scheerens; teachers' licensure examination; licensure review; urban-rural divide

\footnotetext{
*Corresponding author: Fernigil L.Colicol,ferncolicol.fc@gmail.com/flcolicol@up.edu.ph
} 


\section{Introduction}

In 2016, we developed the "LET Intensive Review," a university program for the Licensure Examination for Teachers (LET). We aimed to enhance pre-service teachers' (PSTs) competencies for the LET and raise our institutional performance in the teachers' licensure examination.

In the beginning, the implementation of the review program was subsidized by the Mindanao State University-Tawi-Tawi management. Accordingly, the program fared very well; hence, its renewal year after year. Finally, in 2019, the program reached the university's Board of Regents (BOR), the university system's highest policymaking body, through the proposal of the College of Education for institutionalization and commendable endorsement of the university campus management. Accordingly, the honorable regents acted on and eventually approved the program for institutionalization. With the institutionalization, the review program is now a part of the college's regular offering that helps PSTs in their licensure examination.

The good impression about the review was stirred by the LET results available on the Professional Regulation Commission (PRC) website. Despite this, however, review effectiveness remains speculation in the absence of a thorough program evaluation, hence this study.

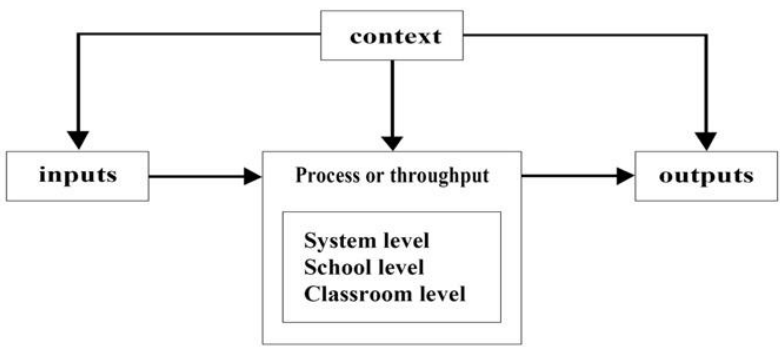

Figure 1: A basic systems model on the functioning of education. Reprinted with permission from the publisher Springer Nature and author Jaap Scheerens

Applying Scheerens's (2011) basic education model, the review is regarded as an input (see Figure 1), a means for achieving an output. According to the model, the functioning of the education system comprises the context, inputs, process, and outputs. The context as the generator of outputs through school goals is crucial. It is the primary source of inputs and where the school and classroom processes (e.g., teaching and learning) occur. On the production function of education, input variables such as "teacher training" and "teacher experience" are vital in achieving educational outcomes (Scheerens \& Bosker, 1997, as cited in Organisation for Economic Co-operation and Development, 2005, p. 15). Equally important is the process that converts school inputs into outputs (Scheerens, 2011).

The Philippine Department of Education (DepEd, 2016) underscored processes relevant to teaching, learning, and governance to achieve quality education in its 
basic education research agenda. Likewise, in higher education (HE), the Commission on Higher Education (CHED) drew attention to processes when it recommended innovation and technology integration in the classroom pedagogy to remedy quality education gaps as reflected in the decline of performance in licensure examinations from 2015 to 2017 (United Nations, 2019). In our case, the 2015 college LET performance paved the way for the LET Intensive Review initiative to raise the institutional performance in the LET and attain the Sustainable Development Goal (SDG) 4: Quality Education. Stipulated under the Philippine Republic Act 7836 (Philippine Teachers Professionalization Act of 1994); the LET is one of the key indicators for assessing educational quality in HE.

The LET Intensive Review evaluation is framed on a transformative paradigm to illuminate and challenge education inequalities (Creswell, 2014; Ghiara, 2020). Along this vein, we use Bourdieu's theoretical framework along with Scheerens's basic education framework. Guided by Bourdieu's theory, James (2014) has proposed a "learning cultures" approach to assessment, curriculum, and teaching and learning to consider social practices through which the learners learn. The approach recognizes the affordances of the context-the economic, political, and social conditions that enable and limit individual action. As such, individuals shape their social context and are also being shaped by it. As theory-as-method, the approach deployed Bourdieu's theoretical tools to explore prevailing social practices in a specific context. From there, it traces the whole range of interconnected social issues affecting the learner, learning performance, and outcomes. James posited that a cultural approach "offers us a productive and useful perspective on some of the day to day practices that embody and produce concepts of knowledge and curriculum in HE" (2014, p. 166). This position accentuates knowledge acquisition as a transformative activity mainly enacted via teaching and learning, resonating that of Ashwin's (2014) notions of "knowledge-as-research, knowledge-as-curriculum and knowledge-as-student understanding" (p. 126). What is sought here is an anthropologically grounded approach to assessment practice indispensable in curriculum development, teaching and learning, and student understanding.

This paper combines a cultural (qualitative) approach with a quantitative approach in a single study to address research questions and achieve the desired evaluation outcome. Bourdieu's anthropology and Scheerens's education ideas constitute examples of how the paradigm or intellectual atmosphere of their time had an impact on their respective theories (Koerner, 1971). Ghiara (2020) shares Koerner's point, stating that a framework reflecting the researcher's views about reality and methodology emanates from a paradigm. A paradigm in the sense of a "worldview" captures the epistemological, ontological, and methodological pluralism used to justify mixed methods research as a combination of different paradigms or philosophical worldviews. Harrits (2011) argues that, in mixed methods research, different paradigms exist. The "paradigmatic differences [occur] at the level of methods, ontology, and epistemology" (p. 150). Harrits's challenge is to "embrace [paradigm] differences instead of imposing homogeneity" in mixed methods research (p. 150). The philosophical basis of 
mixing different paradigms and using the mixed methods approach is John Dewey's pragmatism.

Pragmatism offers an epistemological justification (i.e., via pragmatic epistemic values or standards) and logic (i.e., use the combination of methods and ideas that helps one best frame, address, and provide tentative answers to one's research question[s]) for mixing approaches and methods. A pragmatist would reject a incompatibility thesis and would claim that research paradigms can remain separate, but they also can be mixed into another research paradigm. (Johnson et al., 2007, p. 125)

Based on Ghiara's (2020) notions of epistemological and ontological pluralism and the pragmatists' claim of the validity of mixing different paradigms, transformativism and constructivism are combined with postpositivism for this study. Transformativism and constructivism used to explore PSTs' experiences and meaning-making amid the instances of power differentials and marginalization in their context draw on Bourdieu's anthropological approach. On the other hand, postpositivism deployed to verify qualitative results through quantitative analysis of school outputs builds on Scheerens's education model, which uses measurable indicators under its productivity view of quality education. Thus, combined, the Bourdieu-Scheerens serves as the overarching framework in this study. Founded on the principles of equality and social justice, the Bourdieu-Scheerens promotes a broader definition of the quality of education that is not only outcome-oriented but, more importantly, processoriented (Sayed \& Ahmed, 2015; Scheerens, 2011).

The Bourdieusian framework has a wide range of applications in education. In the HE, it serves a variety of purposes in educational research. For example, there are studies focused on globalization, access, equity, policy, student aspiration, social class, urban-rural inequalities, educational practice, pedagogy, structure and agency, assessment and curriculum, teaching and learning, and evaluation and research (Ferrare \& Apple, 2015; Gale \& Parker, 2015; Hayton \& Bengry-Howell, 2016; James, 2014; Kandlbinder, 2015; Keung \& Ho, 2020; Marginson, 2008; Maton, 2005; Reay, 2018; Rudick et al., 2019; Webb et al., 2017; $\mathrm{Xu}, 2020)$. Of these studies, only Hayton and Bengry-Howell (2016) have focused on evaluation and research, explaining an evaluation framework for widening participation in the English HE system. As a point of argument, they implied a need to develop rigorous evaluation procedures that account for the sociocultural factors in the analysis. This stance provides the rationale of the evaluation framework.

Scheerens's (2011) and Bourdieu's (1977, 1984) theories are invoked and mobilized. Scheerens's education systems model primarily guides the framing of the evaluation questions and the structure of this paper. In a complementary manner, Bourdieu's social theory serves as the main explanatory framework addressing sociocultural issues in education. The analysis includes the school's context, inputs, processes, and outputs, but more attention is given to processes that remain underexplored in education (Gustafsson, 2008; Sayed \& Ahmed, 
2015; Scheerens, 2011). Particular interests are dynamics in pedagogical offerings, instruction, and school climate, shaped by educational policy and practice and highly associated with academic success (Scheerens, 2011). Extensive studies on educational achievement with aims (a) to describe inputs, processes, and outcomes and (b) to explain how factors interact to generate outcomes have been undertaken, but they were mainly policy-driven rather than theory-driven (Gustafsson, 2008). As policies are politically charged and as such contested by differently-positioned actors or groups (Blasco \& Vargas, 2011), the contestations amid the studies implicating a "quality" agenda constrained the studies' aims (Gustafsson, 2008).

A critical examination about education quality in post-2015 education is found in the work of Sayed and Ahmed (2015). The authors investigated the education quality agenda in the United Nations Educational, Scientific and Cultural Organization post-2015 position paper and the Muscat Global Education meeting agreement highlighting, among others, pedagogical processes that include the teachers, teaching, and student outcomes. A case in point is that, while the teachers' vital role is recognized in the agenda, "there is still a failure to engage more broadly with teaching and learning as well as the diverse contexts of teaching and learning" (Sayed \& Ahmed, 2015, p. 330). This eventuality would downplay the quality and equity in education (e.g., provision for teachers salary, education budget, quality of teachers in economically stable and lowincome contexts). Explicitly pointed out is a lack of research along with these gray areas. This study attempts to elucidate processes pertinent to the quality of education. Furthermore, to offer insights on social problems (e.g., inequalities in education, poverty) affecting education quality and equity (DepEd et al., 2017; Pham, 2019; Raza et al., 2019; Vurayai, 2020), this evaluation is situated within the discourse urban-rural divide (Scheerens, 2011; Xu, 2020).

This study evaluates the LET Intensive Review of the Mindanao State University in Tawi-Tawi, Philippines using a transformative mixed methods approach (Creswell, 2014). The approach investigates explicitly the PSTs' LET performance taking into account their sociocultural context.

\subsection{Research Questions}

1. Context: What is the educational situation of the Mindanao State University in Tawi-Tawi vis-à-vis the urban-rural divide?

2. Inputs: What is LET Intensive Review, and what is the impetus to its development?

3. Processes: How does the LET Intensive Review contribute to the LET outcomes?

4. Outputs: What are the passing percentage ratings of the university in the LET elementary and secondary levels for first-timers before (2008-2015) and during (2016-2019) the LET Intensive Review periods?

5. Outputs: Are there significant differences between passing percentage ratings of the university in the LET elementary and secondary levels for first-timers before (2008-2015) and during (2016-2019) the LET Intensive Review periods? 


\section{Explanatory Framework: The Theory of Bourdieu}

The "practice theory" of anthropologist-sociologist Pierre Bourdieu (1930-2002) underlines individuals' interactions in society, whereby they challenge deliberately normative sociocultural systems or concede to them (Bourdieu, 1977; Foley, 2011). To reconcile the structure and agency that constitute society, Bourdieu developed the habitus, field, and capital (Bourdieu, 1977, 1984). Structures, according to Bourdieu (1977), institute "a particular type of environment (e.g. the material conditions of existence characteristic of a class condition)" (p. 72). Following this supposition, individuals conditioned by social class naturally acquire and embody dispositions, which Bourdieu calls the habitus, "systems of durable, transposable dispositions" (p. 72). Habitus resides in the agency; it endows agency with a capacity to actualize a goal and intention.

As opposed to structure, the agency can act independently amid structural constraints, thereby altering structure-agency relations (Harrits, 2011). The habitus mediates the structure and agency (Barrett \& Martina, 2012) as it is "structured structures predisposed to function as structuring structures" (Bourdieu, 1977, p. 72). Henceforth, there is a reciprocal relationship between structure and agency (Marginson, 2008). Habitus generates practices that embody certain forms of strategies (Bourdieu, 1977) which, in turn, enable agents to act opportunistically in a playing field and deal with unexpected situations that are only determined by the future.

To Bourdieu (1984), the capital provides for one's social ascendancy in society. Thus, individuals mobilize their capital resources to maintain their status in the social hierarchy in society. Different forms of capital are cultural, social, and economic capital. Cultural capital, which relates to a person's education, tastes, and lifestyles, can transform into economic capital. On the other hand, economic capital pertains to a person's material possession and affluence. Finally, social capital relates to a person's set of relationships, networks, and connections (Hidalgo et al., 2021; Tonkaboni et al., 2014).

Bourdieu's notion of a field is where individuals socialize, make sense of the social world, and exhibit practices (Bourdieu, 1984). A "social world is understood as a multidimensional space increasingly differentiated into separate, but interconnected 'fields' or cultural contexts. Each of these fields functions according to its own cultural logic and attended with associated forms of 'capital' or cultural resources" (Fries, 2009, p. 330). The practices and their production in the field take shape according to the habitus in the social field or setting.

\subsection{Bourdieu, Education, and Urban-Rural Divide}

The family plays a significant role in capital possession (Costa et al., 2020). Lareau (2003) noted that parents employ different strategies in passing their capital resources to their children. In her study, Lareau pointed out that middleclass families deliberately transfer their capital through concerted cultivation of children's potential, whereas, lower-class families depend on children's natural growth. The varying parental strategies for rearing children (re)produce a differentiated class habitus among families. The middle class, whose norms are 
reflected and valued in schools, has the advantage over its lower-class counterparts. It is suggested here that the capital is pivotal in orchestrating the habitus and that the extent of the habitus transformation matters in educational success.

A point to note is that the acquisition of capital is not exclusive solely within the family circle. As students explore different fields of action, their life's trajectory becomes open to possibilities and change (Marginson, 2008). Thus, when students acquire a particular form of capital, they can also earn other forms of capital. Economic capital, for example, allows participation in different kinds of activities (e.g., reading programs, museum visits, sports, TV viewing) through which students gain cultural capital or linguistic competence and familiarity of the dominant culture (Lareau, 2003; Sullivan, 2002).

Socioeconomic issues related to students' academic performance and educational attainment predominate inequity discourses (DepEd et al., 2017; Pham, 2019; Reay, 2018). In education, inequity is also linked to urban-rural inequality (United Nations Children's Fund \& Southeast Asian Ministers of Education Organization, 2020). Xu (2020) has proposed a framework called the "urban-rural divide" for analyzing inequality in society, in addition to the most common Western-based frameworks such as gender, class, race, and/or ethnic differences. In China, structural inequality regarding the rural and urban, as $\mathrm{Xu}$ pointed out, is due to urban-biased policies.

Closely linked to the urban-rural divide is the "core-periphery model" (Klimczuk \& Klimczuk-Kochańska, 2019). The rendering of this model in this study will serve as an extension of the urban-rural divide framework. The core in this model is construed as the seat of political authority that maintains general social order and usually represents the urban. In contrast, the periphery where the raw materials and resources are outsourced is commonly represented as the rural. This model, known to many economists, sociologists, and development workers, helps tackle socioeconomic developments, regional disparities, power imbalances, and uneven resource allocation. The urban-rural divide in this study is contextualized at the national (metropolis) and provincial levels (Zamora \& Dorado, 2015). In addition, to spell out the relationship between the national and provincial levels (Hannerz, 2001), the core or center in the core-periphery model denotes the national capital (Barnard, 2004). In contrast, the periphery is used to denote the provincial or rural area. The relationship between the core and periphery is embedded in the subsequent discussions.

In urban areas in the United States where students of low-income backgrounds attend school, Barrett and Martina (2012) showed how school administrators and teachers have capitalized on the social and cultural capitals and field by providing high school students with educational services for equity. Raymond Vocational High School has introduced institutional agents; teachers work closely with students of less advantaged backgrounds whereby they build on social support, teach collaboration, cultivate desirable attitudes, and set goals and high expectations. They assist target students in their difficulties and 
provide them support in the forms of advice and encouragement. In their study, Lampert et al. (2016) have underscored that a teacher's family and historical background matters in students' achievements. Simply, a teacher exposed to poverty can better respond to the educational needs of students of lower socioeconomic backgrounds and can better deal with them. On the other hand, as students perceive that their habitus matches their teacher's, they will develop a positive attitude and a sense of belongingness in a learning environment and perform better.

Dewey High School, distinctive with its International Baccalaureate (IB) program, demonstrates how its regulated learning environment shapes students' behavior (Barrett \& Martina, 2012). Building on inclusivity, the school accommodates students coming from different social class backgrounds. Diverse students are socialized in a field characterized by a friendly and competitive learning atmosphere. Despite having experienced difficulties, the less advantaged students acquire needed dispositions and cope with their teachers' and peers' assistance and support. As a result, they become motivated and optimistic about achieving their goals. Along the process, they value learning and realize the purpose of schooling.

Among 26 rural academics of low-income family backgrounds, $\mathrm{Xu}$ (2020), also of rural origin, demonstrated how their rural backgrounds are instrumental in HE and postgraduate studies success. During the academics' postgraduate studies, some feel a sense of distinction and gain pride in their origin, given the university staff's support and constructive guidance. They acquire confidence, motivation, and inspiration to achieve more. The habitus of self-discipline, perseverance, and hard work the academics developed bestows achievements in the academe, granting them cultural capital that they subsequently convert into economic capital by earning for themselves and their families in the rural communities.

In Hayton and Bengry-Howell's (2016) work, habitus, capitals, and field are fundamental components in the evaluation framework for widening participation in the English HE. Giving rise to the framework is a rationale criticizing educational intervention practice devoid of rigorous evaluation procedures and less informed by sociocultural factors that affect the widening access to HE. As an example, as the less advantaged students are socialized in schools where the prevailing norms are middle-class norms, they would commonly experience anxiety, ambivalence, and social exclusion resulting in dropping out (Costa et al., 2020; Reay, 2018). In addressing the exclusionary practices in HE, the educators in Hayton and Bengry-Howell's (2016) study foster students' agency, ensuring they acquire intellectual capital or subject knowledge to navigate the HE field. Tantamount to this is the curriculum from which students learn, acquire capital, and subsequently embody the requisite habitus to transition into HE successfully. 
Informed by the preceding theoretical foundations, this paper brings to light education actors' enactments of agency over school and classroom processes amid affordances and constraints in a school context.

\section{Methodology}

\subsection{Research Design}

The Bourdieu-Scheerens framework is the basis of the research design. The analytical framework integrates the qualitative and quantitative research approaches. Ethnography is the primary research design, supported by descriptive research design. This study, therefore, employed a transformative mixed methods exploratory sequential design (Creswell, 2014). Figure 2 presents the research design.

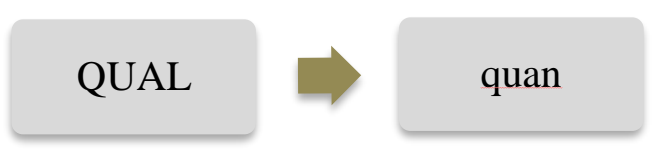

Figure 2: The study research design

\subsection{Data Sources}

As a college program, the LET Intensive Review is realized by an educational policy intending to improve the quality of education. Since the analysis of school policymaking should encompass the state's larger issues brought about by globalization and the new capitalism (Blasco \& Vargas, 2011), we referred to secondary sources of information to acquire a holistic view of the social issues under study, in addition to the field data obtained through observations and interviews (Fetterman, 2010).

As faculty, we actively take part in the university events and programs. In addition, as supervising instructors of PSTs, we had periodic engagements with public school heads and teachers in Tawi-Tawi from 2011 to 2019. In the same period, we conducted a series of observations in DepEd schools while handling PSTs in their field off-campus immersion.

From 2016 to 2019, we were directly involved in the LET Intensive Review program. As program proponents, our advocacy exemplified by our direct engagements with review participants (Low \& Merry, 2010) entailed utmost reflexivity (Creswell, 2014; Fries, 2009). By being reflexive, we critically examined our relationship to our object of study-the issues and the organization we belong to.

We held online interviews via Messenger and Gmail (Angrosino, 2007; Fetterman, 2010) with nine credible PST-key actors (LET passers) chosen from the 2016 to 2019 cohorts of reviewees. The key actors were asked the following open-ended questions: (a) Would you share your success story in the teachers' licensure examination? (b) What insights/reflections/realizations have been learned through the LET Intensive Review? (c) What challenges and difficulties have been encountered, and how have you managed to overcome them? (d) Based on your observation, what are the strengths and weaknesses of the LET 
Intensive Review, or the factors of failure and success in the board exam? And (e) What is your general impression of the LET Intensive Review? What are your comments and suggestions? Furthermore, we asked for feedback from a faculty key actor to enrich the interview data.

Interviews were conducted in April 2019 for the 2016 and 2017 key actors and March 2021 for 2018 and 2019. We acknowledge the limitation of not including non-passers in the pool of key actors. Sensitivity issues hindered them from participating. Nonetheless, we could compensate for such limitations with our long-term immersion in the community and engagements with PSTs. Before our interview with the key actors, we first sought their consent. For this study, the key actors consented to have their names indicated in the paper to associate them with their statements. The rapport that we established during the review opened a smooth and free exchange of ideas online. We sent them the openended questions and gave them enough time to recall and reflect on their past experiences. After obtaining all their responses, we asked them to follow up with closed-ended questions to confirm and clarify information (Fetterman, 2010). Our engagements with them and prolonged observations aided in validating their views, as reflected in their responses.

For the quantitative part of this study, we utilized the LET passing percentage ratings accessible from the Professional Regulation Commission (PRC) website (www.prc.gov.ph). The data were collected and analyzed using a quantitative approach to verify and support the qualitative results. First, we typed and searched "September 2019 LET results" through Google to view the LET ratings. This process was repeated multiple times to search for the 2008 to 2018 ratings, changing only the month (as some exams were held in August and October instead of September) and year. Then, on the commission's webpage, we took note and recorded the national LET passing percentage rate for the elementary and secondary levels (excluding Accelerated Teacher Education Program [ATEP] graduates). Next, we opened the link "Performance of Schools" on the same page and, finally, on the published report, we looked for the university's name and recorded the passing percentage rate for the first-timers. The elementary and secondary levels results are queued on the published report.

\subsection{Data Analysis and Presentation}

Common sense, critical thinking, and interrogation of our positionality mainly informed data analysis (Fetterman, 2010). We first merged the qualitative data gathered from various sources. Then, drawing on the theoretical framework and the related literature, we analyzed them through iterative analysis to answer each research question (Barret \& Martina, 2012; Creswell, 2014; Hayton \& Bengry-Howell, 2016). Theoretical thematic analysis (Braun \& Clarke, 2006) guided our analysis. In ensuring accuracy, secondary sources were examined through content analysis (Fetterman, 2010). Content analysis tests the internal consistency of the text obtained from reports and related documents. The triangulation technique was used to validate the results throughout the process of analysis. The data presented in this paper have passed the validation of competent authority from the studied institution. 
The quantitative data in this study consist of the national passing percentage rating (NPPR), university passing percentage rating (UPPR), and adjusted university passing percentage rating (AUPPR) for elementary and secondary levels first-timers before (2008-2015) and during (2016-2019) the conduct of the LET Intensive Review. For the analysis, the NPPR was needed in addition to the UPPR to adjust the latter and produce the AUPPR. Adjusting the UPPRs generates more robust values that account for the yearly variations in NPPRs. Thus, the AUPPR was produced to become the basis for statistical inferences. The AUPPR was computed by dividing the UPPR by its corresponding NPPR and multiplied by 100. In this paper, the AUPPR data are also presented in a line graph created through Microsoft Excel.

The normalcy of the AUPPR variables (before [2008-2015] and during [20162019] the review) for the elementary and secondary levels, respectively, was tested using the Shapiro-Wilk test (Sheard, 2018) and revealed the data per variable are normally distributed at a level $p>.05$, with the exception of the 2008-2015 elementary level variable: Elementary Level: 2008-2015 $(W=0.79, p=$ $.020)$ and 2016-2019 ( $W=0.97, p=.821)$; and Secondary Level: 2008-2015 ( $W=$ $0.94, p=.631)$ and 2016-2019 $(W=0.93, p=.603)$. Hence, a nonparametric test, the Mann-Whitney $U$ Test, and parametric test, the Independent Samples $t$-test, were used for the elementary and secondary levels, respectively, to test whether there are significant differences between school outputs (analysis based on AUPPRs) before and during the LET Intensive Review periods. $R$ (https://www.r-project.org) software was used in data analysis.

The results of the qualitative and quantitative approaches were analyzed further through integrative analysis to draw the mixed methods research findings.

\section{Results and Discussion}

\subsection{The School Context}

While the university caters to students from all over the Philippines, it mainly accommodates those coming from the island communities of Tawi-Tawi Province.

The province is composed of 11 municipalities spread in the southernmost part of the country. Based on the 2015 census of population, out of the 203 barangays in Tawi-Tawi, 16 fell under the urban barangay category (Philippine Statistics Authority [PSA], 2019a). Per PSA Board Resolution No. 1, series of 2017 (Ratifying and Adopting the Board Resolutions Issued by the Former National Statistical Coordination Board), the basis of urban barangay classification is the following: (a) "with a population size of 5000 or more"; or (b) "with at least one establishment with a minimum of 100 employees"; or (c) "with five or more establishments with 10 to 99 employees, and five or more facilities within the twokilometer radius from the barangay hall" (PSA, 2019b, "Criteria for the Identification" section). Barangays that do not meet any of these classifications are rural. In the 2010 census, of the 366550 total population of Tawi-Tawi, 16.8\%, or 61709 , lived 
in urban barangays, and the rest, $83.2 \%$ or 304841 , resided in rural communities (PSA, 2010).

Based on the preceding report, Tawi-Tawi comprises greater rural communities and lesser urban centers at the provincial level. At the country level, a recent study (see United Nations Children's Fund \& Southeast Asian Ministers of Education Organization, 2020, for the Southeast Asia Primary Learning Metrics [SEA-PLM] 2019 report) among Grade 5 students across Southeast Asia found that the literacy levels of students in the Philippines in writing, reading, and mathematics vary significantly between students residing in the urban and rural areas, such that those in the former outperformed those in the latter. This learning inequity is related to students' socioeconomic status and school location, similar to the Organisation for Economic Co-operation and Development (2005) finding.

In the Philippines, the "rural-urban education inequality gap ... is the main contributor to education inequality" (Zamora \& Dorado, 2015, p. 63). In Tawi-Tawi, inequality in education is strongly associated with the rural-urban gap in the province. As per the PSA report, "individuals residing in [the] rural areas ... posted highest poverty incidences among the basic sectors in 2018" (PSA, 2020b, "Farmers, Fisherfolks, Individuals" section). Tawi-Tawi's poverty incidence rate records in 2015 and 2018 were 15.2 and 15.1, respectively (PSA, 2020a). At this rate, it is worth noting that the province is relatively well-off compared to other provinces in the country and those under the Bangsamoro Autonomous Region in Muslim Mindanao (BARMM). However, this rate was still "comparably high" due to the lowest poverty incidence rate record of 0.7 in 2018.

The PSA report on Functional Literacy, Education and Mass Media Survey (FLEMMS) in 2013 by region has shown that the Autonomous Region in Muslim Mindanao (ARMM) now BARMM, of which Tawi-Tawi is part, had the greatest number of out-of-school youth (OSCY), had lagged in terms of basic literacy rate and functional literacy rate and had a modest proportion of graduates with college or postgraduate degrees (Bersales, 2015). Weak leadership and governance attributed to the region's socio-political dynamics, depressing socioeconomic conditions, and intermittent conflicts contributed to low ARMM educational performance (DepEd et al., 2017). These issues and problems are context-bound, in which the teachers - the education frontliners - do not have control.

A study by Hailaya (2014) in Tawi-Tawi on the National Achievement Test (NAT) results revealed that the Second Year high school and Grade 6 students in the province had "below average" academic achievement, and teachers had "relatively low" assessment literacy (pp. 335-337). Hailaya's findings resonate with the views of Prof. Charmine Puig, a former academic coordinator in the basic education in the province. According to Prof. Puig, the students' weak basic education foundation, as evident in their low performance in Mathematics, English, and Science in the National Achievement Test (NAT), affects their performance at the collegiate level. This trend could be attributed to factors such 
as the observance of many holidays, starting late and early dismissal of classes in remote (rural) schools where monitoring is weak, and the school heads have inadequate technical skills in school management (Puig, personal communication, March 9, 2021).

A reckoning of the long struggle of the BARMM for the political autonomy of the Bangsamoro amid the Philippine developments is necessary to contextualize and understand the education issues in Tawi-Tawi and the entire region (Milligan, 2006).

A significant milestone in the province and the region is creating the BARMM, giving the region the autonomy to fast-track developments and establish measures to address quality education gaps and enhance the quality of education.

\subsection{The School Input and the Impetus to its Development}

Since most basic education graduates in the province enroll at the university for their tertiary education, the university constituency felt the educational challenges in higher education. To respond to some predicaments over students' performance at the tertiary level, consequently, the university devised strategies and intervention programs (e.g., adjustment of admission requirements, the offering of remedial classes, assistance for underprivileged students) to accommodate concerned students and assist them in their transition to the various programs. With such a trend at the tertiary level, it is not unlikely that institutional performance in licensure examinations would be affected as far as overall performance is considered.

For over eight years from 2008 to 2015, although not successively, the previous strategy by the management in assisting graduates in their licensure examinations was to send some outstanding students to mainland Mindanao, providing them with financial assistance to undertake licensure reviews conducted by credible review centers, with a high hope that they not only pass but also top the licensure examinations. Tawi-Tawi then was not yet as highly urbanized as compared with many central areas in mainland Mindanao. Even in Bongao Municipality, the province's capital, limited business establishments and centers provided learning support services. In such a situation, college graduates would need to go to cities like Dipolog or Zamboanga or other places in the mainland Mindanao or Visayas where review centers were operating. They spent much on traveling and lodging expenses and had to adjust to new environments. The institution's strategy partly produced good results with almost a $100 \%$ passing rate in the LET among select graduates; some from the College of Education and the College of Fisheries landed at the top 10 in their respective licensure examinations.

Nonetheless, despite the promising results among select graduates who passed and topped in licensure examinations, the strategy inadequately addressed overall LET performance as most takers could not pass. When most LET takers fail, this means that those who failed in the previous examination will add to the 
bulk of repeaters (those who fail in their first attempt and have to retake the examination) who will be retaking the licensure examination the following year. Hence, any increments made in the first-timers' overall LET performance could hardly be felt in the overall institutional performance (total ratings of first-timers and repeaters) since the repeaters pull down overall LET performance. This situation, coupled with external pressures from the university system and the Commission on Higher Education (CHED), evoked other alternatives from the university, leading to the conception of the LET Intensive Review project in 2016.

The first year of implementation of the LET Intensive Review was experimental. It was a different strategy since it was initiated by the College of Education faculty with the management's support. Unlike the preceding strategy in which select graduates were sent out for their licensure examination preparation, this time the college developed a review program on its own, mobilized available resources in the locality, and, most importantly, conducted the review within the campus in the province.

The review accommodates interested LET takers, but priority is given to graduating students and first-timers. A committee headed by a coordinator, review consultants composed of the College of Education's senior faculty, and review lecturers plays a significant role in the LET Intensive Review. The committee is tasked with logistics, coordinating on-campus and off-campus review lecturers, and preparing the review materials and venue. The review focuses on the LET specifications provided by the Professional Regulation Commission (PRC) with the following components: general education and professional education for the elementary level takers and an additional majorship for the secondary level takers. The review is held during weekends, 8:00 a.m. to 4:30 p.m. on Saturdays and Sundays. It has two parts: Part 1 from January to May, the in-campus review, and Part 2 from May until September, the month of the exam, in which PSTs are provided with financial assistance by the management for their optional review at any review centers.

\subsection{School Processes and Practices}

The PSTs expressed their gratitude and appreciation to the college for the assistance extended throughout their journey in the LET. Shernaiza expressed herself: The "LET intensive review program really helped the College of Education students. I, myself, am really thankful for the intensive review ... because it is a good start for the preparation for LET." Most of them stated the LET Intensive Review was a success made possible through the university support. One has noted:

Apart from our family, the school has also helped us a lot throughout the journey, financially and morally. ... Well, I can say that the LET intensive review program I have attended was a success. Not all of us takers may have passed the exam in one row, but it is said that mostly did. (Josephine)

Foremost, the review that facilitated PSTs' success in the LET was realized through the faculty's agency. The conscious effort to understand the context and 
the people's and students' worldviews amid restraining structures spurred the idea about the program. Other factors in the initiative were pressures from the Commission on Higher Education (CHED) and the university itself. These were the motivation and inspiration behind the faculty's initiative to undertake the program, believing that it was possible to rise above the challenges, transform mindsets, and improve social conditions. On top of this, of course, is the university management's support and approval that granted the authority to implement the review program. In addition, the management's subsidies (monetary allowance) allowed the PSTs to participate in the review program and enjoy its benefits. Indeed, the program was a collective effort of the university personnel who acted as institutional agents to PSTs needing educational services and assistance. The campus administrators, lecturers, faculty, and staff, who were relentless in giving their full support during the whole duration of the review period, shared the PSTs' victories in the LET.

A significant factor worthy of note is the context, mainly the venue where the review took place. Since the program was held within the province, a setting familiar to PSTs, a learning program that considered their social life and context was efficiently designed and implemented. This new arrangement in the review elicits alignment of the habitus and the field, which is advantageous to both the faculty and reviewees. In addition to the affordances in the school context, peer support was a common practice that stimulated learning experiences. Josephine shared: "We sometimes had this group review in the dorm, sharing our ideas and thoughts with those questions and statements that may sound vague to us."

As faculty, our long-term immersion in the community offered rich experiences and knowledge about the sociocultural setting. We were able to establish a code of conduct in the review based on the norms in the community and produce learning guides and kits that are need-based and culture-sensitive. As the leading proponent (main author), my rural background served as a resource in the planning and implementation. All the review lecturers and committee members helped ensure that all the activities, approaches, materials, content, and assessment would contribute to PSTs' readiness for the examination. Zahra manifested in the interview: "During the review program, our minds were being equipped with relevant information and knowledge and trained us how to answer questions similar to that of the actual LET questions."

The design of the review program is holistic. Apart from pure content, we also imparted values and desirable attitudes through group learning, team building, and socialization activities. We took the roles of "big brother" and "big sister" to PSTs to gain their trust and confidence. We constantly gave them advice and encouragement to boost their morale and remind them about our collective goals.

As PSTs were exposed to many learning experiences through the review lectures and sessions, they were engaged in seeking and constructing knowledge by themselves, which broadened their worldviews. From being pessimistic, most of them became optimistic about facing the LET. In the course of the review program, they no longer perceived the review as a burden; instead, they learned 
to enjoy it. In her sharing, Zahra said, "My most awaited part [in] every review was the evaluation in which we were going to answer sets of questions; and I took that as a motivation, especially when I got good scores."

The PSTs enacted their agency by strategy building. Each developed a strategy and routine to facilitate learning and enhance critical thinking. Aldazer shared his strategy: "My review routine was, every night, I answered at least 50 questions. Then I made sure that I engaged myself in reading for at least two hours daily." Resiliency is another trait PSTs learned from the review, and many of them associated it with their strong faith in the Almighty. The sacrifices they poured into the review strengthened them amid dire circumstances. Sheh narrated:

In my first semester, I was tasked to teach 8 different professional education subjects (while I was having my review). ... During the LET, I was only given 45 minutes to answer my GenEd and was forced to finish the test without extension. I was motivated, frustrated and bothered, but I never gave up my dream to pass the LET.

Social constraints hindered PSTs from utilizing the full benefits of the review. These are also the reasons of failure in the LET. Although the university management allocated subsidies, PSTs still fell short in the budget, so they could not attend review sessions regularly. The distance of the review venue from the island communities and the town proper where many PSTs live and the cost for the photocopies of review materials necessitated additional finances for the reviewees. These affected the reviewees and resulted in a lack of interest or low motivation. Missing review lectures meant lagging and weakening established connections with the group and a sense of belonging in the learning environment. Josephine recalled, "There were also those who attended the review sessions but didn't show much effort and interest to learn. It was like being in there just for the sake of attendance." Financial constraint is construed as a shortfall in economic capital. As "the root of all other forms of capital," the economic capital can affect the social and cultural capitals (Bourdieu, 1986, as cited in Xu, 2020, p. 21). In a field with high expectations, some students who lack cultural capital or competencies and whose habitus is not attuned would likely feel anxious, excluded, and unmotivated (Costa et al., 2020; Reay, 2018).

Another area that needs improvement in the review is the area of specialization at the secondary level. Josephine noted, "It has happened to me personally ... some of the topics in the exam seemed so unfamiliar to me (esp. in majorship). ... I just would like to suggest that review for majorship should also be taken into consideration." Inadequate focus on the major courses affected secondary level PSTs' performance in the licensure examination.

\subsection{The School Outputs}

Table 1 presents the NPPR, the UPPR, and the AUPPR data for elementary and secondary levels first-timers, respectively, before (2008-2015) and during (20162019) the LET Intensive Review periods. Figure 3, on the other hand, displays the graph of the AUPPR before and during the LET Intensive Review. 
Table 1: Passing percentage ratings in the Licensure Examination for Teachers (LET) before (2008-2015) and during (2016-2019) the LET Intensive Review periods

\begin{tabular}{|c|c|c|c|c|c|c|}
\hline \multirow[t]{2}{*}{$\begin{array}{l}\text { LET year } \\
\text { (September) }\end{array}$} & \multicolumn{2}{|c|}{$\begin{array}{c}\text { National passing } \\
\text { percentage rating } \\
(\mathrm{NPPR}) \\
\%\end{array}$} & \multicolumn{2}{|c|}{$\begin{array}{c}\text { University passing } \\
\text { percentage rating } \\
\text { (UPPR) } \\
\%\end{array}$} & \multicolumn{2}{|c|}{$\begin{array}{c}\text { Adjusted university } \\
\text { passing percentage } \\
\text { rating (AUPPR) } \\
\%\end{array}$} \\
\hline & Elementary & Secondary & Elementary & Secondary & Elementary & Secondary \\
\hline 2008 & 30.47 & 35.34 & 23.00 & 21.00 & 75.48 & 59.42 \\
\hline 2009 a & 18.67 & 28.15 & 36.00 & 22.00 & 192.82 & 78.15 \\
\hline 2010 & 19.58 & 25.86 & 12.12 & 5.88 & 61.90 & 22.74 \\
\hline 2011 & 22.68 & 31.45 & 10.53 & 30.00 & 46.43 & 95.39 \\
\hline 2012 & 49.29 & 43.50 & 36.90 & 21.62 & 74.86 & 49.70 \\
\hline 2013 & 31.18 & 39.75 & 25.00 & 33.33 & 80.18 & 83.85 \\
\hline $2014^{b}$ & 35.74 & 34.40 & 35.48 & 33.96 & 99.27 & 98.72 \\
\hline 2015 & 31.36 & 41.75 & 12.60 & 30.16 & 40.18 & 72.24 \\
\hline 2016 & 30.18 & 33.78 & 46.15 & 18.18 & 152.92 & 53.82 \\
\hline 2017 & 26.33 & 46.37 & 28.57 & 51.02 & 108.51 & 110.03 \\
\hline 2018 & 20.29 & 48.03 & 27.17 & 47.42 & 133.91 & 98.73 \\
\hline 2019 & 31.34 & 39.68 & 36.89 & 34.52 & 117.71 & 87 \\
\hline
\end{tabular}

Note. AUPPR $=(\mathrm{UPPR} \div \mathrm{NPPR}) \times(100)$

a October examination

${ }^{b}$ August examination

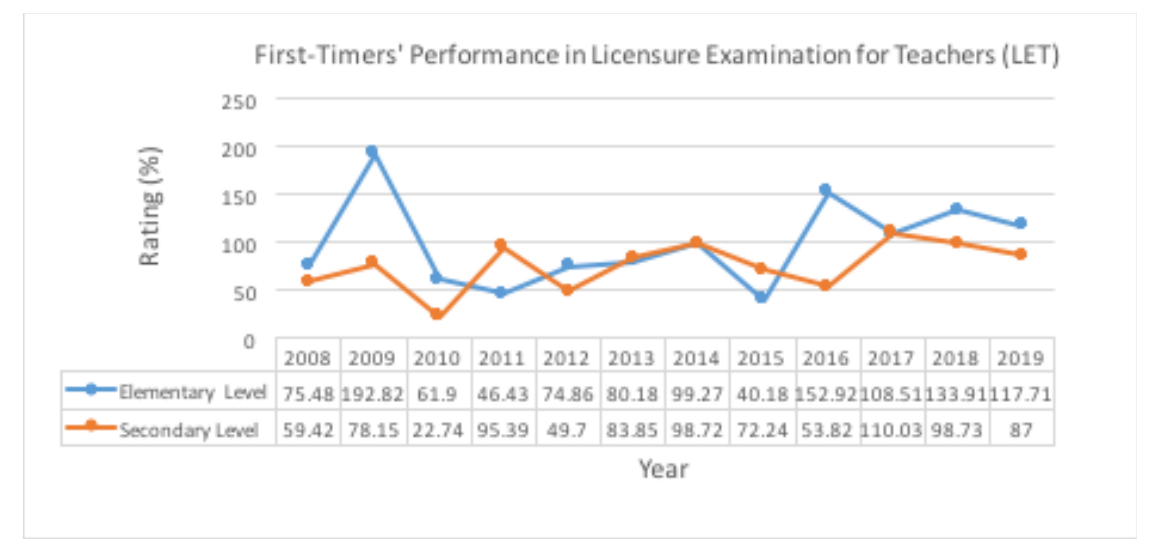

Figure 3: Graph of adjusted university passing percentage ratings (AUPPRs) before (2008-2015) and during (2016-2019) the LET Intensive Review periods

The UPPRs or school outputs (see Table 1) for the LET elementary level firsttimers during the LET Intensive Review period (2016: 46.15\%; 2017: 28.57\%; 2018: $27.17 \%$; and 2019: 36.89\%) were higher than the NPPRs (2016: 30.18\%; 2017: 26.33\%; 2018: 20.29\%; and 2019: 31.34\%), whereas all the UPPRs before the conduct of the review except in 2009 fell below the NPPRs. On the other hand, for the secondary level, the UPPRs or school outputs peaked in 2017, during the review period, with a $51.02 \%$ passing rate and the highest since 2008 , while the rest of the UPPRs fell below the NPPRs.

The Mann-Whitney $U$ test revealed that, at the elementary level, the UPPRs in the LET (based on the AUPPR analysis) were significantly higher during ( $M d n=$ 
125.81) the LET Intensive Review period than the ratings before $(M d n=75.17)$ the review period, $U=4, p=.048$.

At the secondary level, the independent samples $t$-test showed no significant difference in UPPRs in the LET (based on the AUPPR analysis) between the periods before $(M=70.03, S D=25.33)$ and during $(M=87.40, S D=24.28)$ the conducting of the LET Intensive Review, $t(10)=-1.13, p=.283$.

\section{Conclusion}

The PSTs affirmed that the LET Intensive Review was instrumental in their success in the LET. As a teacher preparation and training, the review was a school input actualized by the faculty through the management's support. As faculty, our understanding of the school context and its educational situation steered us to plan, develop, and conduct a review relevant to PSTs' needs and context. The management's approval of the review program and subsidies are noteworthy. The program allowed PSTs to gain institutional support, and the subsidies guaranteed registration and participation in the review. Throughout the review period, the transformation among PSTs was evident, a manifestation that the LET competencies, drills, and exercises have molded their habitus. The school context was a source of constraints and strengths. The province's location posed a challenge for off-campus lecturers from the mainland to come and hold a review in the province. Despite this, the context was strategic since it granted PSTs the convenience and access to material and social support from their families and peers. Simply put, the school processes or contextual habitus were advantageous to most PSTs.

The quantitative analysis of school outputs supports the PSTs' positive views about the LET Intensive Review. Overall, the passing percentage ratings of the university (based on AUPPRs) for the elementary level first-timers were higher during the LET Intensive Review period than the ratings before the review period. This improvement in school outputs means enhanced cultural capital as far as academic performance is concerned. However, at the secondary level, although the highest UPPR (see Table 1) was recorded in 2017, during the review period, the results (based on AUPPRs) did not warrant significant progress in the LET performance. Herein lies the specific area for improvement in the review program: the majorship at the secondary level. Other aspects needing attention are financial constraints, weak basic education foundation, and low motivation during the review. These are perceived factors why many failed in the teachers' licensure examination.

This mixed methods study revealed that the LET Intensive Review is effective based on the elementary level LET results. Apart from the faculty (teacher) agency (Sayed \& Ahmed, 2015), it stood out that the management's support contributed immensely to the school output. Worthy of note here is the administrators' strong will (agency) to implement and institutionalize the program. Hence, this finding suggests that the "administrator agency" deserves attention in analyzing education quality, school performance, and outcomes. 
Furthermore, the findings of this study underline the pragmatic alignments and complementarities of the Bourdieu and Scheerens analytical constructs (see Figure 4). Indeed, the results warrant the integration of Bourdieu's and Scheerens's frameworks. Finally, the framework in this study is open for a probe; thus, subsequent theoretical, methodological, and empirical studies to elaborate and test it are recommended.

\begin{tabular}{|c|c|}
\hline Scheerens framework & Bourdieusian framework \\
\hline Context & Field \\
\hline Inputs & Agency \\
\hline Process & Habitus \\
\hline Outputs & Capital \\
\hline
\end{tabular}

Figure 4: Bourdieu-Scheerens framework: Alignment and complementarity

\section{Policy Implications}

The university management should support the faculty through a well-planned faculty development program to confer cultural capital, foster institutional agency, and address overall performance (including repeaters' performance) in the LET. Furthermore, quality instruction in the basic and higher education levels should be intensified.

Given the move for decentralization (Bautista et al., 2010; Huang et al., 2015), there is a need to capitalize on the province's or countryside's (periphery) potential to deliver quality education. The central government's sensibility on the rural communities' socioeconomic conditions and needs, support, and shared accountability with all the education sectors across all levels are imperative to address education quality and equity issues (de Guzman, 2007). Education authorities must engage all education stakeholders, the education key officials, the government officials (local and national), and the representatives from non-government organizations and the private sector (United Nations Children's Fund \& United Nations Educational, Scientific and Cultural Organization, 2007) for a holistic approach to addressing socioeconomic disparity - a driver of inequality in education - between the urban (core) and rural (periphery) communities.

\section{Acknowledgments}

The LET Intensive Review was started in the university during the terms of Atty. Lorenzo Reyes as Chancellor, now Senior Commissioner of the Legal Education Board, Prof. Benecito Maratas as Vice Chancellor for Academic Affairs, and Prof. Wayne Aripin as College of Education (COED) Dean. The University System Board of Regents (BOR) institutionalized the LET review during the terms of Dr. Mary Joyce Guinto-Sali as Chancellor and Dr. Wilham Hailaya as COED Dean. The authors thank the review lecturers, the review committee members, and consultants for their best efforts in program implementation and the research 
participants who are COED alumni and LET passers. Additionally, the principal author expresses his gratitude to Dr. Teodora Salubayba, Dr. Eufracio Abaya, Dr. Clement Camposano, and Dr. Maria Mercedes Arzadon, his professors and mentors at the University of the Philippines, and to Prof. Elmira ColicolRodriguez, his sister, for her support. Finally, the authors thank the seven anonymous referees who provided feedback, comments, and suggestions to improve this paper.

\section{References}

Angrosino, M. (2007). Doing ethnographic and observational research (U. Flick, Ed.). SAGE Publications.

Ashwin, P. (2014). Knowledge, curriculum and student understanding in higher education. Higher Education, 67, 123-126. https://doi.org/10.1007/s10734-0149715-3

Barnard, A. (2004). History and Theory in Anthropology. Cambridge University Press.

Barrett, B. D., \& Martina, C. A. (2012). Towards a non-deterministic reading of Pierre Bourdieu: Habitus and educational change in urban schools. Policy Futures in Education, 10(3), 249-262. https:// doi.org/10.2304/pfie.2012.10.3.249

Bautista, M. C. R. B., Bernardo, A. B. I., \& Ocampo, D. (2010). When reforms don't transform: Reflections on institutional reforms in the Department of Education. Human Development Network.

Bersales, L. G. S. (2015). 2013 FLEMMS (Functional Literacy, Education and Mass Media Survey): Final report. Philippine Statistics Authority. https://psa.gov.ph/sites/default/files/2013\%20FLEMMS\%20Final\%20Report.p df

Blasco, C. M., \& Vargas, C. A. (2011). Educational policy, anthropology, and the state. In B. A. U. Levinson \& M. Pollock (Eds.), A Companion to the Anthropology of Education (pp. 368-387). Wiley-Blackwell.

Bourdieu, P. (1977). Outline of a Theory of Practice (R. Nice, Trans.). Cambridge University Press. (Original work published in 1972)

Bourdieu, P. (1984). Distinction: A social critique of the judgment of taste (R. Nice, Trans.). Harvard University Press. (Original work published in 1979)

Braun, V., \& Clarke, V. (2006). Using thematic analysis in psychology. Qualitative Research in Psychology, 3(2), 77-101. https://doi.org/10.1191/1478088706qp063oa

Costa, C., Taylor, Y., Goodfellow, C., \& Ecochard, S. (2020). Estranged students in higher education: Navigating social and economic capitals. Cambridge Journal of Education, 50(1), 107-123. https://doi.org/10.1080/0305764X.2019.1648639

Creswell, J. W. (2014). Research design: Qualitative, quantitative, and mixed methods approaches (4th ed.). SAGE Publications.

de Guzman, A. B. (2007). Chronicling decentralization initiatives in the Philippine basic education sector. International Journal of Educational Development, 27(6), 613-624. https://doi.org/10.1016/j.ijedudev.2006.06.014

Department of Education. (2016). Adoption of the basic education research agenda. https://www.deped.gov.ph/wp-content/uploads/2016/06/DO_s2016_039.pdf

Department of Education, Cardno Emerging Markets (Australia) Pty Ltd, United Nations Children's Fund, Deutsche Gesellschaft für Internationale Zusammenarbeit GmbH, \& BRAC Bangladesh. (2017). Annex 4: Factors influencing basic education learning outcomes and teachers' performance in selected public elementary schools in the ARMM: A qualitative assessment. Department of 
Foreign

Affairs

and

Trade.

https://www.dfat.gov.au/sites/default/files/philippines-beam-armm-endprogram-review-annex-4.pdf

Ferrare, J. J., \& Apple, M. W. (2015). Field theory and educational practice: Bourdieu and the pedagogic qualities of local field positions in educational contexts. Cambridge Journal of Education, 45(1), 43-59. https:/ / doi.org/10.1080/0305764X.2014.988682

Fetterman, D. M. (2010). Ethnography: Step-by-step (3rd ed.). SAGE Publications.

Foley, D. (2011). The rise of class culture theory in educational anthropology. In B. A. U. Levinson \& M. Pollock (Eds.), A Companion to the Anthropology of Education (pp. 81-96). Wiley-Blackwell.

Fries, C. J. (2009). Bourdieu's reflexive sociology as a theoretical basis for mixed methods research: An application to complementary and alternative medicine. Journal of Mixed Methods Research, 3(4), 326-348. https:// doi.org/10.1177/1558689809336660

Gale, T., \& Parker, S. (2015). Calculating student aspiration: Bourdieu, spatiality and the politics of recognition. Cambridge Journal of Education, 45(1), 81-96. https:// doi.org/10.1080/0305764X.2014.988685

Ghiara, V. (2020). Disambiguating the role of paradigms in mixed methods research. Journal of Mixed Methods Research, 14(1), 11-25. https://doi.org/10.1177/1558689818819928

Gustafsson, J.-E. (2008). Effects of international comparative studies on educational quality on the quality of educational research. European Educational Research Journal, 7(1), 1-17. https://doi.org/10.2304/eerj.2008.7.1.1

Hailaya, W. M. (2014). Teacher assessment literacy and student outcomes in the province of Tawi-Tawi, Philippines [Doctoral dissertation, The University of Adelaide]. Adelaide Research \& Scholarship. https://digital.library.adelaide.edu.au/dspace/bitstream/2440/99098/2/02wh ole.pdf

Hannerz, U. (2001). Center-periphery relationships. In N. J. Smelser \& P. B. Baltes (Eds.), International Encyclopedia of the Social \& Behavioral Sciences (pp. 1610-1613). Pergamon. https://doi.org/10.1016/B0-08-043076-7/00820-2

Harrits, G. S. (2011). More than method?: A discussion of paradigm differences within mixed methods research. Journal of Mixed Methods Research, 5(2), 150-166. https://doi.org/10.1177/1558689811402506

Hayton, A., \& Bengry-Howell, A. (2016). Theory, evaluation, and practice in widening participation: A framework approach to assessing impact. London Review of Education, 14(3), 41-53. https:/ / doi.org/10.18546/LRE.14.3.04

Hidalgo, G., Monticelli, J. M., \& Bortolaso, I. V. (2021). Social capital as a driver of social entrepreneurship. Journal of Social Entrepreneurship. Advance online publication. https:// doi.org/10.1080/19420676.2021.1951819

Huang, Z., Wang, T., \& Li, X. (2015). The political dynamics of educational changes in China. Policy Futures in Education, 14(1), 24-41. https:// doi.org/10.1177/1478210315612644

James, D. (2014). Investigating the curriculum through assessment practice in higher education: The value of a 'learning cultures' approach. Higher Education, 67, 155169. https://doi.org/10.1007/s10734-013-9652-6

Johnson, R. B., Onwuegbuzie, A. J., \& Turner, L. A. (2007). Toward a definition of mixed methods research. Journal of Mixed Methods Research, 1(2), 112-133. https://doi.org/10.1177/1558689806298224 
Kandlbinder, P. (2015). Signature concepts of key researchers in North American higher education teaching and learning. Higher Education, 69, 243-255. https:// doi.org/10.1007/s10734-014-9772-7

Keung, C. P. C., \& Ho, E. S. C. (2020). Structure and agency in adolescents' expectations of pursuing post-secondary education. Research in Higher Education, 61, 270-295. https://doi.org/10.1007/s11162-019-09574-8

Klimczuk, A., \& Klimczuk-Kochańska, M. (2019). Core-periphery model. In S. Romaniuk, M. Thapa, \& P. Marton (Eds.), The Palgrave Encyclopedia of Global Security Studies (pp. 1-8). Palgrave Macmillan, Cham. https://doi.org/10.1007/978-3-319-74336-3_320-1

Koerner, E. F. K. (1971). Ferdinand de Saussure. Origin and development of his linguistic theory in western studies of language: A critical evaluation of Saussurean principles and their relevance to contemporary linguistic theories. [Doctoral dissertation, Simon Fraser University]. CORE. https://core.ac.uk/download/pdf/56367175.pdf

Lampert, J., Burnett, B., \& Lebhers, S. (2016). 'More like the kids than the other teachers': One working-class pre-service teacher's experiences in a middle-class profession. Teaching and Teacher Education, 58, 35-42. https://doi.org/10.1016/j.tate.2016.04.006

Lareau, A. (2003). Unequal childhoods: Class, race, and family life. University of California Press.

Low, S. M., \& Merry, S. E. (2010). Engaged anthropology: Diversity and dilemmas. Current Anthropology, 51(S2), S203-S226. https:// doi.org/10.1086/653837

Marginson, S. (2008). Global field and global imagining: Bourdieu and worldwide higher education. British Journal of Sociology of Education, 29(3), 303-315. https://doi.org/10.1080/01425690801966386

Maton, K. (2005). A question of autonomy: Bourdieu's field approach and higher education policy. Journal of Education Policy, 20(6), 687-704. https://doi.org/10.1080/02680930500238861

Milligan, J. A. (2006). Reclaiming an ideal: The Islamization of education in the Southern Philippines. Comparative Education Review, 50(3), 410-430.

Organisation for Economic Co-operation and Development. (2005). School factors related to quality and equity: Results from PISA 2000. http://www.oecd.org/education/school/programmeforinternationalstudentas sessmentpisa34668095.pdf

Pham, L. (2019). Capital and capabilities in education: Re-examining Australia's 2015 PISA performance and context assessment framework. Policy Futures in Education, 17(5), 599-617. https:/ / doi.org/10.1177/1478210318808615

Philippine Statistics Authority. (2010). Table 1. Total population, urban population, percent urban, and annual growth rate of urban population by region and province: 2007 and 2010

[Dataset]. https://psa.gov.ph/sites/default/files/attachments/hsd/article/Table\%201_2. pdf

Philippine Statistics Authority. (2019a). Table 3. Number of barangays, number of urban barangays, and percentage of urban barangays by region, province, and highly urbanized city: Philippines, 2015 and 2010 [Dataset]. https://psa.gov.ph/content/urbanpopulation-philippines-results-2015-census-population

Philippine Statistics Authority. (2019b). Explanatory text. https://psa.gov.ph/sites/default/files/attachments/hsd/specialrelease/2015\% 20POPCEN $\% 20 \%$ 20Special $\%$ 20Release $\%$ 20of $\% 20$ Urban $\%$ 20Population $\% 20$ of $\% 2$ 0the\%20Philippines_Urban\%20Rural_Explanatory\%20Text.pdf 
Philippine Statistics Authority. (2020a). Table 9. Updated clustering of provinces based on 2018 full year poverty incidence among families, by province: 2015 and 2018 [Dataset]. https:// psa.gov.ph/content/updated-2015-and-2018-full-year-official-povertystatistics

Philippine Statistics Authority. (2020b, June 3). Farmers, fisherfolk, individuals residing in rural areas and children posted the highest poverty incidences among the basic sectors in 2018 [Press release]. https://psa.gov.ph/content/farmers-fisherfolksindividuals-residing-rural-areas-and-children-posted-highest-poverty

Raza, W. A., Kabir, M. M., \& Rashid, R. (2019). Factors affecting early grade educational attainment: Evidence from South Sudan. International Journal of Educational Development, 65, 92-97. https://doi.org/10.1016/j.ijedudev.2017.08.004

Reay, D. (2018). Working class educational transitions to university: The limits of success. European Journal of Education, 53(4), 528-540. https:// doi.org/10.1111/ejed.12298

Rudick, C. K., Quiñones Valdivia, F. I., Hudachek, L., Specker, J., \& Goodboy, A. K. (2019). A communication and instruction approach to embodied cultural and social capital at a public, 4-year university. Communication Education, 68(4), 438459. https://doi.org/10.1080/03634523.2019.1642501

Sayed, Y., \& Ahmed, R. (2015). Education quality, and teaching and learning in the post2015 education agenda. International Journal of Educational Development, 40, 330338. https://doi.org/10.1016/j.ijedudev.2014.11.005

Scheerens, J. (2011). Perspectives on educational quality. In J. Scheerens, H. Luyten, \& J. van Ravens (Eds.), Perspective on educational quality: Illustrative outcomes on primary and secondary schooling in the Netherlands (pp. 3-33). Springer. https://doi.org/10.1007/978-94-007-0926-3_1

Sheard, J. (2018). Quantitative data analysis. In K. Williamson \& G. Johanson (Eds.), Research Methods (2nd ed., pp. 429-452). Chandos Publishing. https://doi.org/10.1016/B978-0-08-102220-7.00018-2

Sullivan, A. (2002). Bourdieu and education: How useful is Bourdieu's theory for researchers. The Netherland's Journal of Social Sciences, 38(2), 144-166. https://www.researchgate.net/publication/283919595_Bourdieu_and_educatio n_How_useful_is_Bourdieu's_theory_for_researchers

Tonkaboni, F., Yousefy, A., \& Keshtiaray, N. (2014). Designing teaching methods in curriculum of Iran's higher education based on development of social capital. International Journal of Learning, Teaching and Educational Research, 3(1), 21-31. https://www.ijlter.org/index.php/ijlter/article/view/26

United Nations. (2019). The 2019 voluntary national review of the Philippines. https://sustainabledevelopment.un.org/content/documents/23366Voluntary_ National_Review_2019_Philippines.pdf

United Nations Children's Fund \& Southeast Asian Ministers of Education Organization. (2020). SEA-PLM 2019 main regional report. Children learning in 6 Southeast Asian countries. https://www.unicef.org/eap/media/7356/file/SEAPLM\%202019\%20Main\%20Regional\%20Report.pdf

United Nations Children's Fund \& United Nations Educational, Scientific and Cultural Organization. (2007). A human rights-based approach to education for all [E-book]. https:// www.right-to-education.org/sites/right-toeducation.org/files/resource-attachments/A\%20Human\%20Rightsbased \%20Approach\%20to\%20Education\%20for\%20All_0.pdf

Vurayai, S. (2020). Rurality and exclusion in ordinary level mathematics in Zimbabwe: A document analysis. International Journal of Learning, Teaching and Educational Research, 19(6), 370-386. https://doi.org/10.26803/ijlter.19.6.22 
Webb, S., Burke, P. J., Nichols, S., Roberts, S., Stahl, G., Threadgold, S., \& Wilkinson, J. (2017). Thinking with and beyond Bourdieu in widening higher education participation. Studies in Continuing Education, 39(2), 138-160. https://doi.org/10.1080/0158037X.2017.1302926

$\mathrm{Xu}, \mathrm{C}$. L. (2020). Tackling rural-urban inequalities through educational mobilities: Ruralorigin Chinese academics from impoverished backgrounds navigating higher education. Policy Reviews in Higher Education. Advance online publication. https://doi.org/10.1080/23322969.2020.1783697

Zamora, C. M. B., \& Dorado, R. A. (2015). Rural-urban education inequality in the Philippines using decomposition analysis. Journal of Economics, Management $\mathcal{E}$ Agricultural Development, 1(1), 63-71. https://jemadonline.weebly.com/uploads/2/6/9/7/26975871/ruralurban_education_inequality_in_the_philippines_using_decomposition_analysis. pdf 